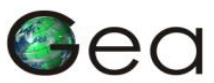

JURNAL PENDIDIKAN GEOGRAFI

\title{
STANDAR PROSES PEMBELAJARAN GEOGRAFI PADA KURIKULUM 2013
}

\author{
Ahmad Yani \\ Departemen Pendidikan Geografi, FPIPS, UPI, email: ahyani_70@yahoo.co.id
}

\begin{abstract}
ABSTRAK
Objek kajian geografi sejatinya ada yang berbentuk konkrit dan sebagian ada yang terkategori "abstrak". Seseorang baru dapat mengetahui adanya persebaran suatu objek, interaksi antar ruang, interelasi, interdependensi, dan adanya proses yang bekerja dalam ruang jika telah divisualisasikan dalam peta, tabel, grafik, gambar, angka statistik, dan atau visual animasi. Sifat kajian geografi tersebut tentu saja memiliki implikasi terhadap pembelajaran geografi di sekolah apalagi ada kewajiban untuk disampaikan melalui pembelajaran dengan pendekatan saintifik. Implementasi pendekatan saintifik pada mata pelajaran geografi akan mudah jika tersedia data sekunder yang berasal dari berbagai instansi yang berwenang dan jika lokasi observasi lapangan relatif dekat dengan lokasi sekolah. Oleh karena itu, pengelolaan waktu pertemuan di kelas, sebaiknya berorientasi pada efektivitas pembelajaran dan bukan semata-mata memenuhi lima langkah saintifik pada setiap pertemuan.
\end{abstract}

Kata kunci: standar proses, geografi, Kurikulum 2013, saintifik.

\section{PENDAHULUAN}

Ada empat komponen perubahan yang menyertai pemberlakukan Kurikulum 2013, yaitu perubahan pada Standar Kompetensi Lulusan, Standar Isi, Standar Proses, dan Standar Penilaian. Tulisan ini hanya akan membahas tentang perubahan Standar Proses dan implikasinya terhadap proses pembelajaran di ruang kelas, dan lebih khusus lagi implikasi terhadap pembelajaran geografi pada jenjang Sekolah Menengah Atas (SMA). Tulisan ini menjadi sangat penting untuk dikaji, karena proses pembelajaran adalah "ujung tombak" peningkatan mutu pendidikan baik dalam skala satuan pendidikan maupun pada skala pendidikan nasional.

Adanya perubahan standar proses pada Kurikulum 2013 adalah berdasarkan Peraturan Menteri Pendidikan dan Kebudayaan (Permendikbud) Republik Indonesia Nomor 65 Tahun 2013 Tentang Standar Proses Pendidikan Dasar dan Menengah sebagai pengganti dari Peraturan Menteri Pendidikan Nasional
(Permendiknas) Republik Indonesia Nomor 41 Tahun 2007 Tentang Standar Proses untuk Satuan Pendidikan Dasar dan Menengah. Jika ditelaah secara cermat, maka sekurang-kurangnya ada empat perubahan yang paling mendasar yaitu: 1) Pengembangan silabus; pada Permendiknas RI Nomor 41 Tahun 2007 tentang Standar Proses, penyusunan silabus merupakan beban guru sehingga klosulnya adalah bahwa pengembangan silabus dapat dilakukan oleh para guru secara mandiri atau berkelompok dalam sebuah sekolah/madrasah atau beberapa sekolah, kelompok Musyawarah Guru Mata Pelajaran (MGMP) atau Pusat Kegiatan Guru (PKG), dan Dinas Pendidikan. Sedangkan pada (Permendikbud) RI Nomor 65 Tahun 2013 tentang Standar Proses disusun dan dikembangkan oleh Kementerian Pendidikan dan Kebudayaan dan bukan menjadi kewajiban guru; 2) Kegiatan inti pembelajaran; pada Permendiknas RI Nomor 41 Tahun 2007 tentang Standar Proses direkomendasikan 
(diwajibkan) untuk menggunakan metode meliputi tahapan proses Eksplorasi, Elaborasi, dan Konfirmasi (sering disingkat EEK). Sedangkan pada Permendikbud RI Nomor 65 Tahun 2013 tentang Standar Proses, pendekatan pembelajaran yang direkomendasikan adalah tematik, tematik terpadu, saintifik, inkuiri, discovery, project based learning, atau problem based learning. Tahapan proses pembelajaran diatur melalui Permendikbud RI Nomor 81a Tahun 2013 Tentang Implementasi Kurikulum, Lampiran IV yang menjelaskan bahwa proses pembelajaran terdiri atas lima pengalaman belajar pokok yaitu Mengamati, Menanya, Mengumpulkan Informasi, Mengasosiasi; dan Mengkomunikasikan (sering disingkat 5M); 3) Kurikulum 2013 mengembangkan dua modus proses pembelajaran yaitu proses pembelajaran langsung dan proses pembelajaran tidak langsung. Penjelasannya diurai pada Permendik-bud RI Nomor 81a Tahun 2013 Tentang Implementasi Kurikulum, Lampiran IV. Dalam pembelajaran langsung peserta didik melakukan kegiatan belajar mengamati, menanya, mengumpulkan informasi, mengasosiasi atau menganalisis, dan mengkomunikasikan apa yang sudah ditemukannya dalam kegiatan analisis. Proses pembelajaran langsung menghasilkan pengetahuan dan keterampilan langsung atau yang disebut dengan instructional effect. Pembelajaran tidak langsung adalah proses pendidikan yang terjadi selama proses pembelajaran langsung tetapi tidak dirancang dalam kegiatan khusus. Pembelajaran tidak langsung berkenaan dengan pengembangan nilai dan sikap. Pada kurikulum sebelumnya (Kurikulum 2006) tidak banyak diatur tentang pembelajaran tidak langsung; 4) Integrasi pendidikan karakter pada setiap mata pelajaran; pada kurikulum 2006 tidak diatur secara rinci sedangkan pada Kurikulum 2013 berdasarkan pada Permendikbud RI Nomor 81a Tahun 2013 Tentang
Implementasi Kurikulum dengan klosul bahwa baik pembelajaran langsung maupun pembelajaran tidak langsung (harus) terjadi secara terintegrasi dan tidak terpisah. Pembelajaran langsung berkenaan dengan pembelajaran menyangkut KD yang dikembangkan dari KI-3 dan KI-4. Keduanya, dikembangkan secara bersamaan dalam suatu proses pembelajaran dan menjadi wahana untuk mengembangkan KD pada KI-1 dan KI-2 (kompetensi spiritual dan sosial yang keduanya memiliki muatan nilai-nilai pendidikan karakter). Pembelajaran menyangkut KD yang dikembangkan dari KI-1 dan KI-2 bersifat tidak langsung.

Berdasarkan pada latar belakang di atas, tentu saja akan banyak tuntutan terhadap guru. Setiap guru bidang studi akan mengkaji ulang dan mengadaptasi karakteristik mata pelajaran-nya dengan ketentuan yang berlaku. Mata pelajaran matematika akan berbeda dengan pengelolaan pembelajarannya (pembagian waktu dan pengembangan strategi pembelajarannya) dengan mata pelajaran bahasa Indonesia. Begitu pula mata pelajaran olah raga akan berbeda jauh dengan implementasi pembelajarannya dengan geografi. Jika Anda guru geografi, maka pertanyaannya adalah bagaimana pembelajaran geografi yang sesuai dengan ketentuan standar proses?

Tulisan ini akan mencoba mengupas strategi pembelajaran geografi sesuai ketentuan standar proses dalam konteks implementasi Kurikulum 2013. Kajian akan dibagi tiga sub bab yaitu (1) Karakteristik mata pelajaran Geografi; (2) Landasan teori pendekatan saintifik dalam konteks Kurikulum 2013; dan (3) Implementasi standar proses (pendekatan Saintifik) dalam pembelajaran Geografi. Adapun tujuan kajian adalah ingin memberi pemahaman tentang pengelolaan pembelajaran geografi dalam konteks pendekatan saintifik agar pembelajaran lebih efektif dan efisien. Metode kajiannya adalah analisis pustaka dengan pendekatan secara kualitatif. 


\section{KARAKTERISTIK MATA PELAJARAN GEOGRAFI}

Geografi berasal dari dua suka kata yaitu geo dan graphien. Geo artinya bumi dan graphien artinya tulisan, gambaran, atau pen-jelasan. Dalam perjalanannya, definisi ilmu geografi selalu mengalami penyesuaian. Pendapat Richard Hartshorne yang dikutif oleh Sumaatmadja (1997; 9) tentang geografi adalah "geography is that discipline that seeks to describe and interpret the variable character from place to place of the earth as the world of man". Hartshorne ingin menekankan bahwa tempat kehidupan manusia memiliki perbedaan-perbedaan karakter, dan ilmu geografi berusaha mencari penjelasan dan interpretasi tentang karakter tempat-tempat di permukaan bumi

Bintarto dalam Maryani (2009:3) menyatakan bahwa geografi merupakan ilmu pengetahuan yang menceritakan, menerangkan sifat-sifat bumi, menganalisis gejala-gejala alam dan penduduk, serta mempelajari corak khas kehidupan dan mencari fungsi dari unsur-unsur bumi dalam ruang dan waktu. Komite Rediscovering Geography yang didirikan tahun 1993 di Amerika Serikat dalam publikasinya yang berjudul Rediscovering Geography New Relevance for Science and Society $(1997 ; 40)$ juga menerangkan bahwa geografi tradisional tertarik pada integrasi antara fenomena dan proses dalam ruang dengan mrngatakan bahwa "geography's traditional interest in integrating phenomena and processes in particular places". Lebih lanjut Komite Geografi juga memberi penjelasan karakteristik geografi, bahwa geografi:

In its explorations as a science of flows, geography has been a leader in understanding spatial interactions, as subject of broad interest to both science and society. Moreover, geography's long standing concern with interdependencies among scales in relevant to discussions across the body of science of relationships between microscale (small or local) and macroscale (large or global) phenomena and processes.

(Rediscovering Geography Committee, 1997; 4).

Pernyataan di atas memperkuat bahwa geografi merupakan ilmu yang mengawali dalam kaji tentang interaksi spasial dan tertarik untuk mengkaji hubungan antara ilmu pengetahuan (alam) dengan masyarakat. Jauh sebelum pengertian yang diajukan oleh Komite Geografi, Rhoad Murphey dalam Sumaatmadja (1981; 36) menyebutkan tiga ruang lingkup kajian geografi yaitu distribution, interrelation-ship, dan regional framework. Ketiga bidang kajian di atas dijelaskan sebagai berikut: 1) The distribution and relationship of mankind over the earth and the spatial aspects of human settlement and the use of the earth; 2) The interrelationship between human society and the physical environment as part of the study of areal differences; 3) The regional framework and the analysis of specific region.

J.A. Sporck dan O. Tulippe yang dikutip juga oleh Sumaatmadja (1981: 37) mengatakan bahwa peranan ilmu geografi adalah ilmu yang mengkaji relasi keruangan dengan mengatakan bahwa "geography as the study of spatial relations of phenomena". Dalam mengkaji relasi keruangan, seringkali para ilmuwan geografi menelusuri berbagai faktor yang mempengaruhi timbulnya suatu keadaan dan kejadian tertentu. Untuk itu, dibutuhkan kecermatan dalam mencari faktor penyebab, mengidentifikasi dan mencari relasi dari faktor-faktor tesebut sehingga mempengaruhi munculnya suatu keadaan atau kejadian. Dalam mengidentifikasi faktor penyebab, para ahli akan memperhatikan banyak faktor baik faktor alam, sosial, ekonomi, budaya, dan lainnya.

Antar faktor yang mempengaruhi diidentifikasi relasinya, baik dalam hubungan sebab akibat maupun pengelompokkan dan pemetaan permasalahan. Faktor alam mempengaruhi faktor sosial, atau sebaliknya faktor sosial mempengaruhi faktor alam. Dengan demikian 
untuk memahami suatu keadaan atau kejadian di permukaan bumi dibutuhkan wawasan yang komprehensif dan mencari relasi antar faktor yang rasional. Untuk dapat memahami relasi keruangan, geografi menggunakan tiga pendekatan. Haggett dalam Maryani (2009; 8) menyebutkan tiga pendekatan geografi yaitu analisis keruangan (spatial analysis), analisis ekologi (ecological analysis), dan analisis kompleks wilayah (regional complex analysis). Analisis keruangan memandang bahwa di dalam ruang permukaan bumi terdapat unsur fisik dan unsur manusia yang tersusun membentuk suatu keadaan, pola, dan proses ruang. Champan menyebutnya spatial context, spatial pattern, dan spatial process (Maryani, 2009; 8). Analisis ekologi memandang ruang permukaan bumi adalah suatu ekosistem yang di dalamnya terjadi interaksi antar organisme hidup dan antara organisme hidup dengan lingkungannya. Adapun analisis kompleks wilayah merupakan kombinasi antara analisis keruangan dan analisis ekologi.

Berdasarkan uraian di atas, karakteristik objek kajian geografi sejatinya ada yang berbentuk konkrit dan sebagian ada yang terkategori "abstrak". Seseorang baru dapat mengetahui adanya persebaran suatu objek, interaksi antar ruang, interelasi, interdependensi, dan adanya proses yang bekerja dalam ruang jika telah divisualisasikan dalam peta, tabel, grafik, gambar, angka statistik, dan secara visual melihat pergerakan baik orang, hewan, angin, barang, dan jasa antar ruang. Sebagian orang akan merasakan (atau menyadari) peranan interaksi antar ruang, manakala terjadi hambatan dan atau kekurangan dalam pemenuhan kebutuhan. Contoh, kita baru menyadari pentingnya peranan distribusi sembilan bahan pokok (sembako) manakala di pasar terjadi kelangkaan beras akibat jalur transportasi mengalami hambatan tanah longsor. Atau kita merasa "memiliki" kepala, manakala kepala kita terbentur tiang listrik.
Sifat kajian geografi yang dijelaskan di atas tentu saja memiliki implikasi terhadap pembelajaran geografi di sekolah. Peserta didik diharapkan mampu memahami suatu fenomena dan proses permukaan bumi tidak hanya dilihat dari kasus per kasus tetapi harus dikaitkan antara fenomena dan proses di tempat lain, bahkan di waktu sebelumnya. Fenomena dan proses dalam suatu ruang tidak cukup dijelaskan dengan hanya menyebutkan nama-nama atau istilah-istilah terkait, tetapi guru harus mampu menyajikan ilustrasi persoalannya secara lebih konkrit.

Untuk dapat memahami fenomena dan proses geografi, dibutuhkan kehadiran berbagai media yaitu kebutuhan akan peta, tabel, grafik, gambar, angka statistik, dan visualisasi gambar diam, animasi, maupun film. Materi geografi akan mudah diajarkan kepada perserta didik, setelah fenomena dan proses geografi tersebut "diolah" sedemikian rupa sehingga menjadi lebih konkrit. Karakteristik ini perlu disampaikan agar guru geografi tidak menyamakan mata pelajaran geografi dengan biologi atau fisika. Mata pelajaran biologi mungkin dapat dengan mudah mempelajari fisiologi sistem pencernaan kodok karena ukurannya kecil, kodoknya dapat dipegang, perutnya dibelah, lalu sistem pencernaannya digambar dalam bentuk bagan alir. Beberapa objek kajian fisika juga dapat disimulasikan dan atau diuji coba eksperimen dalam ruang tertentu.

Geografi jelas berbeda dengan mata pelajaran tersebut. Objek kajiannya sangat luas karena permukaan bumi sehingga untuk melihat keseluruhan dibutuhkan alat untuk memperkecil, yaitu peta. Proses distribusi, interaksi ruang, interdependensi antar wilayah, dan sejenisnya tidak dapat diamati secara langsung seperti halnya kodok. Dengan karakteristik demikian, kelak akan banyak mengalami sedikit kesulitan ketika ada aturan yang mengharuskan pembelajaran geografi menggunakan pendekatan pembelajaran saintifik. Jika diilustrasikan secara 
sederhana, bahan ajar geografi dapat modifikasi proses informasi yang bertahap. diajarkan dengan baik setelah melalui

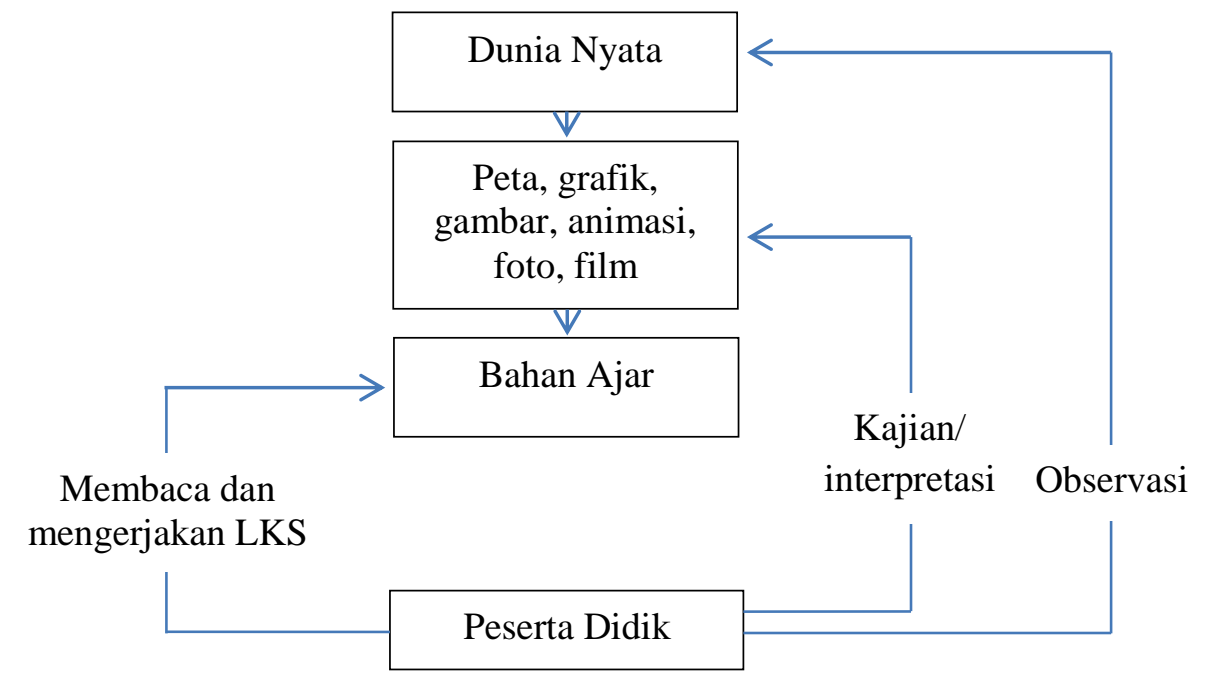

Gambar 1. Bahan Ajar Geografi

Gambar 1 dapat dijelaskan bahwa peserta didik dapat mengakses lingkungan dunia nyata sebagai sumber belajar dengan cara mengobservasi. Secara metodologis, observasi lapangan sangat baik, tetapi tidak dapat memberi gambaran yang cukup untuk memahami objek studi geografi yang sesungguhnya. Observasi lapangan hanya memiliki tiga tujuan yaitu untuk memastikan kebenaran objek dari apa yang tertera dalam peta (memastikan data), mengumpulkan satuan-satuan data yang dianggap penting dalam konteks sistem lingkungan yang lebih luas, dan mencari perspektif lain dalam melakukan analisis data geografi. Jika peserta didik belum memahami tujuan observasi lapangan, maka akan mengalami kegagalan dalam memahami materi geografi secara utuh. Peserta didik (barangkali) akan lebih mudah jika mengakses data yang ada sudah tersedia dalam bentuk peta, grafik, gambar, animasi, foto, dan film dalam proses belajar. Data yang ditampilkan pada "media" tersebut telah dipermudah untuk dibaca karena ditonjolkan pada bagian yang memiliki kesamaan dan atau perbedaannya sehingga mudah difahami.

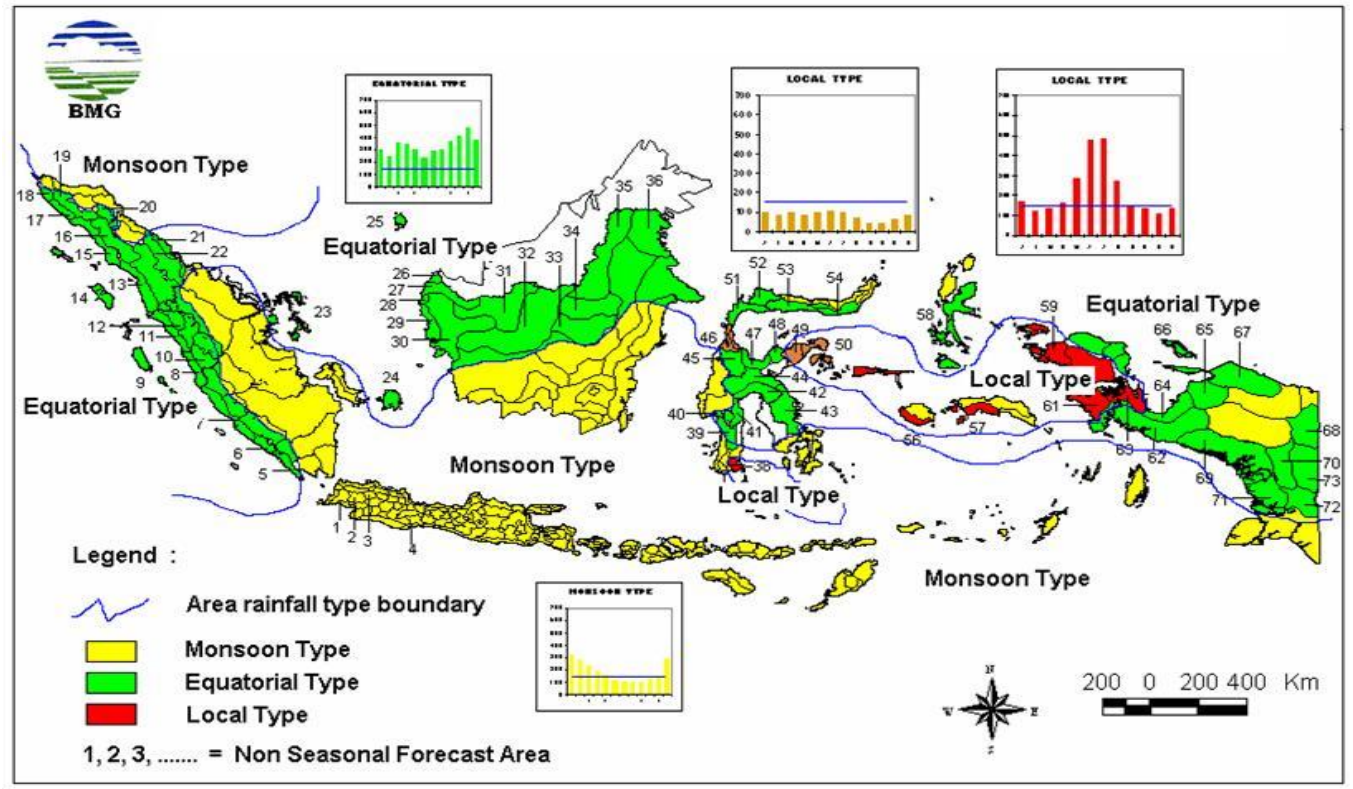

Gambar 2. Peta pola curah hujan di Indonesia (Sumber: BMG) 
Adanya media di atas, peserta didik akan lebih mudah menganalisis data geografi. Bayangkan jika harus melakukan observasi sendiri! Selain tidak cukup waktu juga tidak cukup keahliannya. Namun demikian, akan lebih mudah lagi jika peta dan grafik di atas dinarasikan atau dijelaskan guru. Walaupun "pengalaman" belajarnya lebih rendah tetapi informasinya akan mudah difahami. Mengapa demikian?, karena peta, grafik dan bagan tidak menyajikan informasi yang mempengaruhi terwujudnya peta, grafik, dan bagan. Jika dinarasikan, maka informasi yang dibutuhkan untuk pendalaman materi dapat disajikan.

\section{LANDASAN TEORI PENDEKATAN SAINTIFIK DALAM KURIKULUM 2013}

Pendekatan saintifik adalah nama lain dari pendekatan keterampilan proses yaitu pembelajaran yang mengajak peserta didik untuk melakukan proses penelitian. Dalam model ini peserta didik dilatih melakukan kegiatan layaknya ilmuwan (scientist) dalam melakukan penyelidikan ilmiah. Tujuan utama adalah untuk mengembangkan sikap ilmiah dan membina keterampilan belajar (basic learning tools) dalam mengembang-kan dirinya secara mandiri. Langkah pembelajaran saintifik mengadopsi langkah penelitian ilmiah (gambar 3).

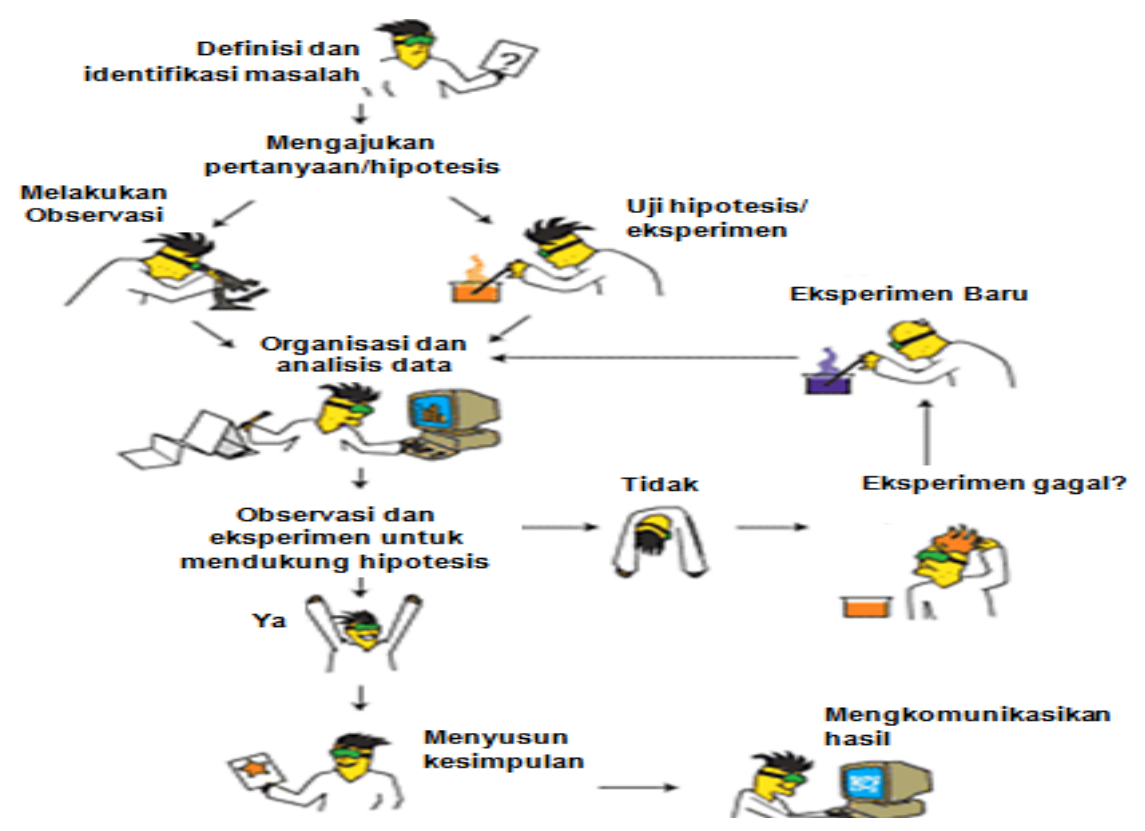

Gambar 3. Langkah penelitian ilmiah

(Sumber: http:/ / fikarzone.wordpress.com dan Ahmad Yani, 2014)

Berdasarkan gambar 3, peserta didik diajak untuk belajar (mandiri dan kelompok) untuk melakukan hal-hal sebagai berikut: 1) Mengidentifikasi masalah; 2) Mengajukan pertanyaan/ hipotesis; 3) Berdasarkan pertanyaan dan hipotesis yang diajukan, peneliti selanjutnya melakukan observasi atau melakukan eksperimen di laboratorium; 4) Setelah data terkumpul, kegiatan berikutnya adalah mengorganisasi dan analisis data. Bentuknya mengklasifikasi data, membuat tabel dan grafik, mengkorelasikan data, atau uji-t untuk mengetahui perbedaan data; 5) Menyusun kesimpulan yaitu melakukan interpretasi terhadap hasil penelitian; 6) Mengkomunikasikan hasil yaitu kegiatan publikasi hasil penelitian.

Langkah kegiatan penelitian tersebut dijadikan landasan untuk mengembangkan sintaks atau langkah pembelajaran. Pembelajaran berbasis pada kerja ilmiah (saintifik) secara teoritik menurut Subiyanto (1988) hanya mencakup dua kelompok 
keterampilan yaitu keterampilan dasar meliputi observasi, klasifikasi, komunikasi, pengukuran, prediksi, dan penarikan kesimpulan dan keterampilan terintegrasi meliputi mengidentifikasi variabel, menyusun tabel data, menyusun grafik, menggambarkan hubungan antar variabelvariabel, memperoleh dan memproses data, menganalisis investigasi, menyusun hipotesis, merumuskan variabel secara operasional, merancang investigasi, dan melakukan eksperimen. Rustaman, dkk. (2004) mengurut-kan keterampilan proses sains atas sembilan langkah yaitu observasi, interpretasi, klasifikasi, prediksi, komunikasi, berhipotesis, merancang percobaan, menerapkan konsep, dan mengajukan pertanyaan.

Landasan teori pemberlakukan pendekatan saintifik sebenarnya sudah ada rambu-rambunya yaitu dari Permendikbud Nomor 65 tahun 2013 tentang Standar Proses Bab IV Pelaksanaan pembelajaran yang menjelaskan bahwa untuk memperkuat pendekatan tematik terpadu dan saintifik disarankan untuk menerapkan belajar berbasis penyingkapan/penelitian (discovery/ inquiry learning). Untuk mendorong peserta didik menghasilkan karya kreatif dan kontekstual, baik individual maupun kelompok, disarankan menggunakan pendekatan pembelajaran yang menghasilkan karya (project based learning) dan atau berbasis pemecahan masalah (problem based learning).

Landasan utama dari apa yang disebutkan di atas sumber awalnya adalah discovery/inquiry learning. Landasan psikologi belajarnya adalah pendekatan konstruktivis Jean Piaget dan Jerome Bruner. Jean Piaget terkenal dengan proses berpikir pada anak. Ada dua proses yang terjadi dalam perkembangan dan pertum- buhan kognitif anak yaitu proses asimilasi dan akomodasi. Asimilasi adalah proses menyesuaikan atau mencocokkan hal yang baru diketahui dengan apa yang telah diketahui sebelumnya. Pada proses asimilasi, konsep baru dapat menggantikan konsep yang telah diketahuinya atau sebaliknya akan mempertahankan konsep yang terdahulu. Sedangkan akomodasi adalah menyusun dan membangun kembali apa yang telah diketahui sebelumnya sehingga informasi yang baru itu dapat disesuaikan dengan lebih baik. Kelak teorinya lebih dikenal dengan teori konstruktivistik.

Jerome Bruner dikenal sebagai penemu teori discovery learning walaupun ide-idenya mirip dengan penulis sebelumnya yaitu John Dewey. Bruner berpendapat bahwa "practice in discovering for oneself teaches one to acquire information in a way that makes that information more readily viable in problem solving" (Bruner, 1961, p. 26). Motto teorinya adalah "belajarnya dengan menemukan". Penerapannya di kelas, belajar diarahkan untuk berlatih mengajukan solusi dan mengatasi masalah, belajar dengan cara menghasilkan sesuatu (project), belajar dengan melakukan observasi, berinteraksi dengan lingkungannya dengan cara mengeksplorasi, diajurkan untuk bergulat dengan pertanyaan yang menarik untuk dijawab lewat penelitian, suka dengan gagasan kontroversi, dan lebih banyak belajar dengan melakukan percobaan.

Langkah pembelajaran keterampilan proses sains yang daijukan para ahli banyak ragamnya. Namun Permendikbud No. 81A Tahun 2013 tentang Implementasi Kurikulum Bagian Pedoman Umum Pembelajaran memberi ketetapan bahwa langkah pembelajaran saintifik berikut.

Tabel 1. Kegiatan Belajar Berdasarkan Lima Langkah Pembelajaran Saintifik

\begin{tabular}{cll}
\hline LANGKAH & \multicolumn{1}{c}{ KEGIATAN BELAJAR } & \multicolumn{1}{c}{$\begin{array}{l}\text { KOMPETENSI YANG } \\
\text { DIKEMBANGKAN }\end{array}$} \\
\hline MEMBELAJARAN & $\begin{array}{l}\text { Membaca, mendengar, menyimak, } \\
\text { melihat (tanpa atau dengan alat) }\end{array}$ & $\begin{array}{l}\text { Melatih kesungguhan, ketelitian, } \\
\text { mencari informasi }\end{array}$ \\
\hline
\end{tabular}




\begin{tabular}{|c|c|c|}
\hline $\begin{array}{c}\text { LANGKAH } \\
\text { PEMBELAJARAN }\end{array}$ & KEGIATAN BELAJAR & $\begin{array}{c}\text { KOMPETENSI YANG } \\
\text { DIKEMBANGKAN }\end{array}$ \\
\hline Menanya & $\begin{array}{l}\text { Mengajukan pertanyaan tentang } \\
\text { informasi yang tidak dipahami dari apa } \\
\text { yang diamati atau pertanyaan untuk } \\
\text { mendapatkan informasi tambahan } \\
\text { tentang apa yang diamati (dimulai dari } \\
\text { pertanyaan faktual sampai ke } \\
\text { pertanyaan yang bersifat hipotetik) }\end{array}$ & $\begin{array}{l}\text { Mengembangkan kreativitas, rasa ingin } \\
\text { tahu, kemampuan merumuskan } \\
\text { pertanyaan untuk membentuk pikiran } \\
\text { kritis yang perlu untuk hidup cerdas dan } \\
\text { belajar sepanjang hayat }\end{array}$ \\
\hline $\begin{array}{l}\text { Mengumpulkan } \\
\text { informasi/ } \\
\text { eksperimen }\end{array}$ & $\begin{array}{l}\text { melakukan eksperimen } \\
\text { membaca sumber lain selain buku teks } \\
\text { mengamati objek/ kejadian/aktivitas } \\
\text { wawancara dengan nara sumber }\end{array}$ & $\begin{array}{l}\text { Mengembangkan sikap teliti, jujur, } \\
\text { sopan, menghargai pendapat orang lain, } \\
\text { kemampuan berkomunikasi, } \\
\text { menerapkan kemampuan } \\
\text { mengumpulkan informasi melalui } \\
\text { berbagai cara yang dipelajari, } \\
\text { mengembangkan kebiasaan belajar dan } \\
\text { belajar sepanjang hayat. }\end{array}$ \\
\hline $\begin{array}{l}\text { Mengasosiasikan/ } \\
\text { mengolah informasi }\end{array}$ & $\begin{array}{l}\text { mengolah informasi yang sudah } \\
\text { dikumpulkan baik terbatas dari hasil } \\
\text { kegiatan mengumpulkan/eksperimen } \\
\text { mau pun hasil dari kegiatan mengamati } \\
\text { dan kegiatan mengumpulkan } \\
\text { informasi. } \\
\text { Pengolahan informasi yang } \\
\text { dikumpulkan dari yang bersifat } \\
\text { menambah keluasan dan kedalaman } \\
\text { sampai kepada pengolahan informasi } \\
\text { yang bersifat mencari solusi dari } \\
\text { berbagai sumber yang memiliki } \\
\text { pendapat yang berbeda sampai kepada } \\
\text { yang bertentangan. }\end{array}$ & $\begin{array}{l}\text { Mengembangkan sikap jujur, teliti, } \\
\text { disiplin, taat aturan, kerja keras, } \\
\text { kemampuan menerapkan prosedur dan } \\
\text { kemampuan berpikir induktif serta } \\
\text { deduktif dalam menyimpulkan. }\end{array}$ \\
\hline Mengkomunikasikan & $\begin{array}{l}\text { Menyampaikan hasil pengamatan, } \\
\text { kesimpulan berdasarkan hasil analisis } \\
\text { secara lisan, tertulis, atau media lainnya }\end{array}$ & $\begin{array}{l}\text { Mengembangkan sikap jujur, teliti, } \\
\text { toleransi, kemampuan berpikir } \\
\text { sistematis, mengungkapkan pendapat } \\
\text { dengan singkat dan jelas, dan } \\
\text { mengembangkan kemampuan berbahasa } \\
\text { yang baik dan benar. }\end{array}$ \\
\hline
\end{tabular}

\section{IMPLEMENTASI STANDAR PROSES (PENDEKATAN SAINTIFIK) DALAM PEMBELAJARAN GEOGRAFI}

Pertanyaan pertama yang diajukan oleh hampir setiap guru dalam setiap diskusi tentang Permendikbud Nomor 81A Tahun 2013 tentang Implementasi Kurikulum adalah apakah pendekatan saintifik termasuk pendekatan yang mudah dilaksanakan di kelas? Apakah setiap mata pelajaran dan setiap pertemuan "wajib" melalui lima langkah saintifik?. Guru geografi juga sering bertanya: apakah mungkin setiap pekan atau setiap bulan melakukan observasi lapangan untuk setiap topik materi geografi?. Semua pertanyaan terus muncul sebagai pertanda kebijakan tersebut mengandung masalah. Tulisan ini mencoba mengajukan alternatif atau solusi untuk mengatasi permasalahan yang dihadapi.

Pertanyaan pertama, apakah pendekatan saintifik mudah dilaksanakan di kelas? Jawabannya tentu sangat relatif. Bisa mudah dan bisa juga sangat sulit. Untuk matapelajaran tertentu tertentu, seperti biologi, fisika, dan kimia yang didukung oleh sumber belajar yang melimpah (seperti laboratorium, internet, bahan bacaan, dan lain-lain), maka langkah saintifik akan lebih mudah diterapkan. Dianggap mudah karena peserta didik tidak perlu beranjak dari sekolahnya. Mereka dapat melakukan eksperi-men, 
mencari data dari berbagai sumber di sekolahnya. Namun jika sumber belajarnya terbatas, maka tentu saja pendekatan saintifik akan sulit dilakukan. Pada mata pelajaran geografi, implementasi pendekatan saintifik akan mudah (1) jika tersedia data sekunder yang berasal dari berbagai instansi yang berwenang seperti Badan Pusat Statistik (BPS), BMG, data kependudukan, data distribusi barang, peta tematik, dan sejenisnya yang dibutuhkan dalam studi geografi; (2) jika lokasi observasi lapangan relatif dekat dengan lokasi sekolah. Sebaliknya akan menjadi sulit dan hampir-hampir tidak dapat diterapkan di kelas, jika tidak tersedia data, tidak tersedia media dan alat pembelajaran, dan lokasi observasi lapangan jauh dari lokasi sekolah.

Pertanyaan kedua, apakah setiap mata pelajaran "wajib" seragam mengandung lima langkah saintifik dalam setiap pertemuan?. Permendikbud RI Nomor 103 Tahun 2014 Tentang Pembelajaran pada Pendidikan Dasar dan Pendidikan Menengah memberi rambu-rambu bahwa jika memungkinkan setiap pertemuan mengandung lima langkah saintifik yaitu Mengamati, Menanya, Mencari Informasi, Mengasosiasi, dan Mengkomunikasikan (5M), namun demikian jika diduga tidak akan efektif maka lima langkah pembelajaran tidak harus muncul seluruhnya dalam satu kali pertemuan tetapi dapat dilanjutkan pada pertemuan berikutnya, tergantung cakupan muatan pembelajaran. Yani (2014) mengusulkan, dalam pengelolaan waktu pertemuan di kelas harus berorientasi pada efektivitas pembelajaran dan bukan semata-mata memenuhi lima langkah saintifik pada setiap pertemuan. Dengan demikian kita memperoleh banyak alternatif dalam melakukan pembagian waktu pertemuan. Contoh: Jika dalam silabus dialokasikan waktu 4 pertemuan, maka dapat membagi waktu sbb.

Pertemuan 1: Mengamati + menanya + mencari informasi/ eksperimen + mengasosiasi + mengkomunikasikan
Pertemuan 2: Mengamati + menanya + mencari informasi/ eksperimen + mengasosiasi + mengkomunikasikan

Pertemuan 3: Mengamati + menanya + mencari informasi/ eksperimen + mengasosiasi + mengkomunikasikan

Pertemuan 4: Mengamati + menanya + mencari informasi/ eksperimen + mengasosiasi + mengkomunikasikan

Alternatif kedua membagi waktu sbb.:

Pertemuan 1: Mengamati + menanya

Pertemuan 2: Mencari informasi/ eksperimen

Pertemuan 3: Mengasosiasi

Pertemuan 4: mengkomunikasikan

Atau bisa juga sebagai berikut:

Pertemuan 1: Mengamati + menanya

Pertemuan 2: Mencari informasi/ eksperimen + mengasosiasi

Pertemuan 3: Mengkomunikasikan

Pertemuan 4: Mengkomunikasikan

Pilihan mana yang terbaik tergantung pada karakteristik pokok bahasannya. Untuk mata pelajaran geografi, sebaiknya memperhatikan ketersediaan sumber belajar. Bagi sekolah yang minim sumber belajar dan atau minim media pembelajaran, sebaiknya memperbanyak kegiatan Mengamati saja untuk "mengejar" penyampaian materi. Langkah kegiatan lainnya yaitu Menanya, Mencari data (observasi), Mengasosiasi, dan Mengkomunikasikan cukup dilakukan sekemampuan saja, namun demikian harus tetap memiliki semangat untuk tetap berusaha melatih peserta didiknya dalam mencoba langkahlangkah saintifik. Ruang lingkup, tema, atau topik yang diangkat untuk latihan melakukan langkah saintifik dipilih yang paling mudah dan sederhana sederhana sehingga memungkinkan peserta didik dapat terlibat dan mempraktikannya. Guru tidak perlu memaksakan diri memilih tema yang sulit karena akan mubadzir dan tidak bermakna bagi peserta didik. Sebaliknya bagi sekolah yang memiliki sumber belajar atau sumber data geografi melimpah, guru dapat memilih tema yang relevan dan dibutuhkan oleh peserta didik. 
Sebagai contoh, pada materi Dinamika dan Masalah Kependudukan (Kelas XI) terdiri dari 24 jam pelajaran (4 jam x 6 pertemuan) dengan ruang lingkup materi sebagai berikut: 1) Sumber data kependudukan; 2) Kuantitas dan analisis demografi; 3) Kualitas penduduk; 4) Mobilitas penduduk dan pengendaliannya; 5) Permasalahan kependudukan di Indonesia dan solusinya; 6) Peta jalan (road map) pengembangan Sumber Daya Manusia Indonesia. Dari enam tema di atas, guru dapat memilih salah satu tema saja yang akan "dipraktikkan" melalui langkah saintifik. Pemilihan tema dapat mempertimbangkan faktor kelayakan dan memungkinkan untuk dikerjakan oleh peserta didik. Peneliti memiliki anggapan bahwa untuk mata pelajaran geografi, tema pada setiap pokok bahasan tidak harus keseluruhan dipraktikkan. Jika guru dan peserta didik hanya mampu melaksanakan suatu sub tema kecil dari pokok bahasan (misalnya hanya mencari data komposisi penduduk berdasarkan jenis kelamin dan usia untuk menentukan sex rasio), maka lakukan saja tanpa ragu. Jika data dsekunder tersedia lebih banyak, maka langkah saintifik ditingkatkan untuk mengitung angka pertumbuhan penduduk, angka kepadatan pendiduk, dan lain-lain. Jika guru memiliki data yang lebih banyak, maka tugasnya ditingkatkan lagi.

Pembelajaran saintifik sejak ditetapkan dalam peraturan menteri, telah banyak dipersepsi secara berlebihan oleh guru. Pengawas sekolah yang umumnya juga awam, menambah keruh suasana ketakutan karena pendapatnya seperti perintah "raja" yang tidak boleh dilanggar, sehingga langkah santifik menambah sulit untuk dikembangkan. Keresahan ini sedikit-banyaknya telah ikut berpengaruh terhadap penundaan implementasi Kurikulum 2013 di awal tahun 2015.

Persepsi negatif apa yang membuat guru menjadi resah? Persepsi yang keliru itu antara lain bahwa guru seolah-olah tidak memiliki kesempatan untuk "menuntaskan" materi pelajaran padahal geografi masih dibayang-bayangi oleh Ujian Nasional. Persepsi yang benar adalah bahwa pada setiap langkah saintifik, guru sangat leluasa untuk menyam-paikan materi pelajaran pada setiap langkah saintifik. Pada langkah Mengamati, guru dapat menjelaskan materi pelajaran. Pada langkah Menanya, guru dapat mengulas kembali materi yang belum difahami. Pada langkah Mencari data, guru dapat membimbing siswa memilih data geografi yang dibutuhkan dan menambah wawasan materi geografi. Pada langkah Komunikasi, guru kembali memperoleh kesempatan untuk menyampaikan materi ajar yang belum dimengerti oleh peserta didik. Dari penjelasan di atas, guru leluasa untuk mengejar materi di sela-sela waktu langkah saintifik.

Bahkan ada satu keunggulan dengan pembelajaran saintifik yaitu dapat mengem-bangkan (mengintegrasikan) nilainilai pendidikan karakter dari Kompetensi Inti Spiritual (KI-1) dan Kompetensi Inti Sosial (KI-2) pada setiap materi. Misalnya pada saat mengamati, guru dapat memberi sugesti agar anak mau menghargai orang lain, pada saat mencari data guru dapat memberi sugesti agar peserta didik mau berlaku jujur, dan seterusnya. Pada saat komunikasi, guru dapat memberi motivasi untuk terus belajar dan meningkatkan rasa ingin tahu.

Pertanyaan ketiga adalah apakah mungkin guru geografi selalu melakukan observasi lapangan pada setiap pekan?. Jawabannya pasti tidak mungkin. Apa yang harus dilakukan? Guru harus memiliki rencana pengelolaan kelas untuk mengakomodasi lima langkah saintifik, caranya sebagai berikut: 1) Tetapkan tema kecil (atau sederhana) yang akan dijadikan topik penelitian dalam konteks pembelajaran saintifik. Setiap bab, wajib dipilih salah satu tema yang memungkinkan dapat dilakukan di kelas masing-masing. Tema "penelitian" tersebut dapat satu, dua, atau lebih. Tema-tema penelitian dapat 
ditugaskan kepada peserta didik baik secara individual maupun kelompok yang telah dibentuk di kelas masing-masing; 2) Rencanakan pembagian waktu untuk menerapkan langkah saintifik. Sebagaimana telah diterangkan, guru dapat merencanakan langkah-langkah $5 \mathrm{M}$ pada setiap pertemuan atau diatur sedemikian rupa sehingga suatu pertemuan hanya diisi oleh satu langkah saintifik saja dan atau pertemuan berikutnya diisi dengan langkah-langkah lainnya dalam saintifik; 3) Siapkan sumber belajar yang akan dikunjungi oleh peserta didik. Jika akan dibawa ke perpustakaan, pastikan peserta didik akan memperoleh data yang ditugaskan di perpustakaan. Jika akan melakukan observasi lapangan, guru juga harus memastikan bahwa di lapangan terdapat data yang dapat diambil oleh peserta didik; 4) Siapkan media, alat, dan perlengkapan pembelajaran yang dibutuhkan seperti LCD, bahan tayang, Lembar Kerja Siswa (LKS), dan instrumen isian yang dibutuhkan sesuai langkah pembelajaran; 5) Siapkan instrumen penilaian hasil belajar baik instrumen aspek sikap, pengetahuan, maupun keterampilan sebagaimana diatur dalam Permendikbud Nomor 104 Tahun 2014 Tentang Penilaian Hasil Belajar Oleh Pendidik Pada Pendidikan Dasar dan Pendidikan Menengah; 6) Pelaksanaan pembelajaran dengan mengunakan metode dan strategi yang berorientasi pada peserta didik. Sebagaimana, Permendikbud Nomor 65 tahun 2013 tentang Standar Proses Bab IV Pelaksanaan Pembelajaran menjelaskan bahwa untuk memperkuat pendekatan saintifik disarankan untuk menerapkan belajar berbasis penyingkapan/penelitian (discovery/inquiry learning), pembelajaran yang menghasilkan karya (project based learning) dan atau berbasis pemecahan masalah (problem based learning).

Apa hubungan antara pendekatan saintifik dengan pendekatan discovery/ inquiry learning, project based learning, dan problem based learning?. Ketiga strategi yang disebutkan di atas merupakan adalah satu "gen". Discovery/ inquiry learning adalah landasan teori dari pembelajaran saintifik. Jika guru merancang pembelajaran saintifik dengan target agar peserta didik menghasilkan karya tertentu maka guru tersebut sudah mengkolaborasikan saintifik dengan strategi project based learning, sebaliknya jika produk peserta didik hanya berupa konsep solusi maka guru tersebut dapat dikatakan telah mengkolaborasikan saintifik dengan strategi problem based learning. Dengan asumsi di atas, maka jika ada guru yang berpendapat dan atau menerapkan salah satu pendekatan dari discovery/inquiry learning, project based learning, atau problem based learning di kelas, maka tidak dapat disalahkan karena pada dasarnya mereka telah melaksanakan pendekatan saintifik juga.

Bagaimana perbedaan antara pembelajaran yang bersifat tradisional dengan saintifik? Pembelajaran tradisional biasanya akan merumuskan apa yang harus diketahui, informasi yang diajarkan lalu diingat, dan masalah (dalam berbagai dimensi kehidupan) hanya dijadikan contoh dan ilustrasi. Sedangkan pembelajaran saintifik diawali dari pemahaman masalah dan ditugaskan untuk dipelajari atau diteliti oleh peserta didik. Selanjutnya peserta didik melakukan identifikasi apa yang perlu diketahui, dan hasilnya adalah menerapkan dan mengkomunikasikan untuk memecahkan masalah.

Jika diterapkan dalam pembelajaran geografi, guru harus mengidentifikasi masalah atau tema yang akan diangkat menjadi bahan pembahasan, bahan diskusi, bahan latihan penelitian, dan bahan yang akan dikerjakan. Tema yang dapat diangkat dalam geografi misalnya urbanisasi, banjir, angka kelahiran, produktivitas pertanian, sebaran barang tambang, dan lain-lain.

\section{SIMPULAN}

Karakteristik objek kajian geografi ada yang berbentuk konkrit dan sebagian lainnya berbentuk "abstrak", karena 
geografi mempelajari persebaran, interaksi, interelasi, interdependensi, dan berbagai proses yang bekerja dalam ruang dalam skala yang besar. Objek kajian akan nampak dan mulai terlihat ketika sudah divisualisasikan dalam bentuk peta, tabel, grafik, gambar, angka statistik, dan animasi. Dengan sifat kajian geografi yang dijelaskan di atas, memiliki implikasi terhadap pembelajaran geografi di sekolah. Mata pelajaran geografi yang disampaikan melalui pendekatan saintifik memiliki kesulitan terutama pada penyediaan dan pengemasan sumber belajar, serta pengelolaan kelas pada langkah ketiga yaitu observasi lapangan. Solusi yang dapat dijadikan alternatif untuk mengatasi masalah tersebut adalah guru (sekolah) menyediakan data sekunder dari berbagai instansi terkait seperti dari Badan Pusat Statistik (BPS), BMG, data kependudukan, data distribusi barang, peta tematik, dan sejenisnya yang dibutuhkan dalam studi geografi. Dengan cara tersebut, peserta didik tidak harus langsung mengakses objek lapangan untuk pencarian data primer tetapi cukup mengakses data sekunder. Walaupun demikian tidak mengurangi kualitas proses atau langkah pembelajaran saintifik geografi.

Berdasarkan kajian ini, teridentifikasi bahwa tanggung jawab guru yang cukup berat adalah menyediakan berbagai sumber belajar dan atau data sekunder yang akan digunakan peserta didik dalam melakukan kegiatan belajar dengan pendekatan saintifik, discovery, atau inquiry. Untuk mengurangi beban guru, sekolah dan para pihak berkepentingan (stakeholder) dapat membantu guru dengan cara menyediakan atau memberi data sekunder kepada sekolah yang selanjutkan guru mengoleksinya untuk memenuhi kebutuhan belajar peserta didik.

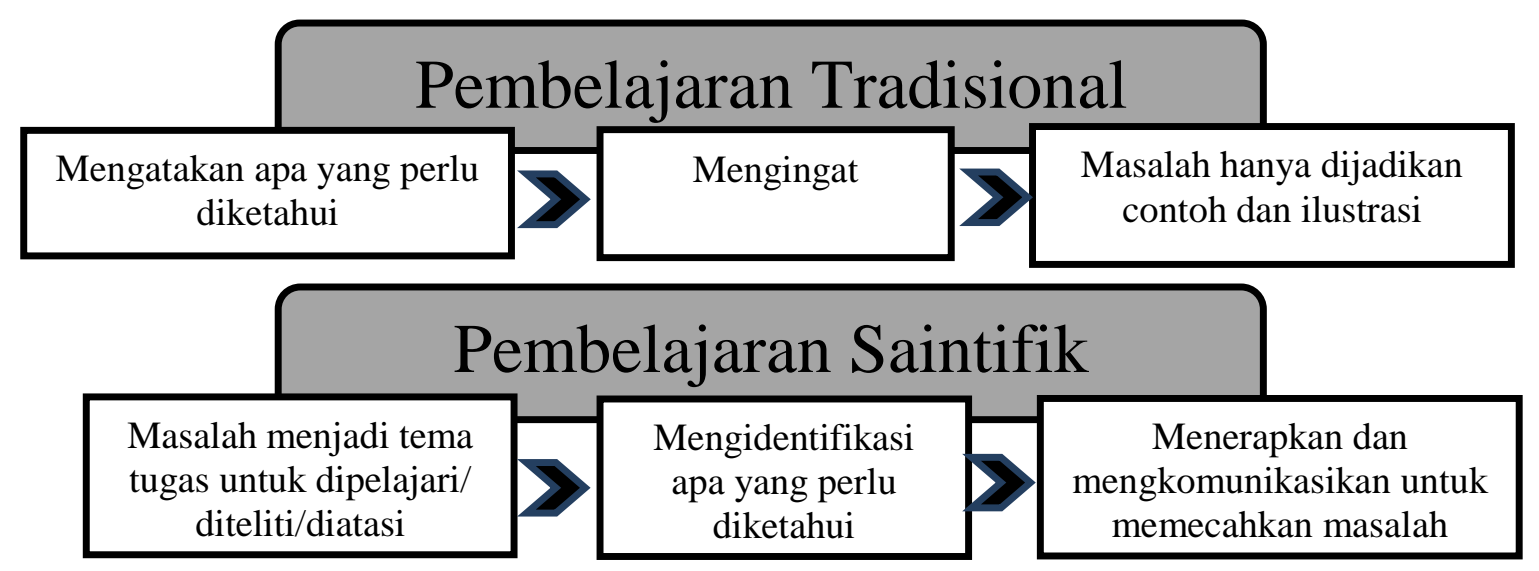

Gambar 4. Kedudukan "masalah" dalam pembelajaran tradisional dan pembelajaran saintifik

\section{DAFTAR PUSTAKA}

Bintarto, R. dan Hadisumarno, S. (1987). Metode Analisis Geografi. Jakarta. LP3ES.

Maryani, E. (2009). Kompilasi Pendidikan Geografi dalam Konteks IPS. Bandung. Jurusan Pendidikan Geografi FPIPS UPI.

Permendikbud RI ndonesia Nomor 65

Tahun 2013 Tentang Standar Proses Pendidikan Dasar dan Menengah

Permendikbud RI Nomor 65 tahun 2013

Tentang Standar Proses Bab IV Pelaksanaan

Pembelajaran
Permendikbud RI Nomor 81a Tahun 2013 Tentang Implementasi Kurikulum, Lamp. IV Permendiknas RI Nomor 41 Tahun 2007 Tentang Standar Proses.

Sumaatmadja, N. (1997). Metodologi Pengajaran Geografi. Jakarta. Bumi Aksara.

Sumaatmadja, N. (1981). Studi Geografi Suatu Pendekatan dan Analisa Keruangan. Bandung : Alumni.

Yani, A. (2014). Mindset Kurikulum 2013. Bandung Alfabeta. 